\title{
Communication
}

\section{Evolution of catalytic activity driven by structural fusion of icosahedral gold cluster cores}

\author{
Dan Yang, Yan Zhu * \\ School of Chemistry and Chemical Engineering, Nanjing University, Nanjing 210093, Jiangsu, China
}

\section{A R T I C L E I N F O}

\section{Article history:}

Received 18 April 2020

Accepted 21 May 2020

Published 5 February 2021

\section{Keywords:}

Gold cluster

Structure fusion

Icosahedral unit

Oxidation of pyrrolidine

Active sites

Catalytic activity

\begin{abstract}
A B S T R A C T
Atomically precise gold cluster catalysts have emerged as a new frontier in catalysis science, owing to their unexpected catalytic properties. In this work, we explore the evolution of the catalytic activity of clusters formed by the structural fusion of icosahedral $\mathrm{Au}_{13}$ units, namely $\mathrm{Au}_{25}(\mathrm{SR})_{18}$, $\mathrm{Au}_{38}(\mathrm{SR})_{24}$, and $\mathrm{Au}_{25}\left(\mathrm{PPh}_{3}\right)_{10}\left(\mathrm{SC}_{2} \mathrm{H}_{4} \mathrm{Ph}\right)_{5} \mathrm{Cl}_{2}$, in the oxidation of pyrrolidine to $\gamma$-butyrolactam. We demonstrate that the structural fusion of icosahedral $\mathrm{Au}_{13}$ units, forming vertex-fused (vf), face-fused (ff), and body-fused (bf) clusters, can induce a decrease in the catalytic activity in the following order: $\mathrm{Au}_{\mathrm{bf}}>\mathrm{Au}_{\mathrm{ff}}>\mathrm{Au}_{\mathrm{vf}}$. The structural fusion of icosahedral $\mathrm{Au} 13$ units in the clusters does not distinguish the adsorption modes of pyrrolidine over the three clusters from each other, but modulates the chemical adsorption capacity and electronic properties of the three clusters, which is likely to be the key reason for the observed changes in catalytic reactivity. Our results are expected to be extendable to study and design atomically defined catalysts with elaborate structural patterns, in order to produce desired products.
\end{abstract}

(C) 2021, Dalian Institute of Chemical Physics, Chinese Academy of Sciences. Published by Elsevier B.V. All rights reserved.
Recently, ligand-capped $\mathrm{Au}_{n}$ clusters ( $n=$ number of gold atoms, ranging from a dozen to hundreds) with precise atomic structures have attracted considerable interest. Significant advances have been made in the synthesis and unambiguous structural determination of atomically precise $\mathrm{Au}_{n}$ clusters [1-4]. These clusters are unique and substantially different from their larger nanoparticle counterparts (typically 3-100 $\mathrm{nm})$, as the former exhibit a range of fascinating optical, electronic, and magnetic properties [5], which are not observed in the latter. Small $\mathrm{Au}_{n}$ clusters (relative to $\mathrm{Au}_{144}$, that is, smaller than $1.7 \mathrm{~nm}$ ) exhibit molecular-like behavior such as single-electron transitions or excitons; relatively larger ones (between $\mathrm{Au}_{144}$ and $\mathrm{Au}_{333}$, i.e., 1.7-2.3 nm) exhibit intermediate properties between molecular and metallic behavior [6-8]; clusters of size larger than that of $\mathrm{Au}_{333}$ (> $2.3 \mathrm{~nm}$ ) can be classified as metallic. Overall, the molecular or non-metallic behav- ior of $\mathrm{Au}_{n}$ clusters in excitonic and transition regimes is particularly important in catalysis, where these systems often display unexpected catalytic performances in some important chemical reactions, and exhibit a clear correlation between properties and structure [9-13].

More importantly, precisely controlling the structure of clusters has proved to be a valuable strategy to improve catalytic activity and tune product selectivity. For example, although $\mathrm{Au}_{28}(\mathrm{SPh}-\mathrm{tBu})_{20}$ and $\mathrm{Au}_{28}\left(\mathrm{~S}-\mathrm{c}-\mathrm{C}_{6} \mathrm{H}_{11}\right)_{20}$ have the same $\mathrm{Au}_{20}$ core, the different surface structure of the two clusters can result in different catalytic activity and selectivity toward $\mathrm{CO}_{2}$ hydrogenation [14]. The structural evolution from the mono-icosahedral $\left[\mathrm{Au}_{13}\left(\mathrm{PPh}_{3}\right)_{10} \mathrm{X}_{2}\right]^{3+}$ to the bi-icosahedral $\left[\mathrm{Au}_{25}\left(\mathrm{PPh}_{3}\right)_{10}\left(\mathrm{SC}_{2} \mathrm{H}_{4} \mathrm{Ph}\right)_{5} \mathrm{X}_{2}\right]^{2+}$ and even to the tri-icosahedral $\left[\mathrm{Au}_{37}\left(\mathrm{PPh}_{3}\right)_{10}\left(\mathrm{SC}_{2} \mathrm{H}_{4} \mathrm{Ph}\right)_{10} \mathrm{X}_{2}\right]^{+}$cluster also illustrates the structure-dependent effects on CO oxidation [15]. Even the replace-

\footnotetext{
* Corresponding author. Tel: +86-25-89681696; E-mail: zhuyan@nju.edu.cn This work was supported by the National Natural Science Foundation of China $(21773109,91845104)$. DOI: 10.1016/S1872-2067(20)63659-2 | http://www.sciencedirect.com/science/journal/18722067 | Chin. J. Catal., Vol. 42, No. 2, February 2021
} 
ment of only a central atom of a cluster by a foreign atom can have substantial influence on the catalytic activity [16-18]. Therefore, the study of atomically precise clusters in catalytic applications opens a new avenue for the design of catalysts with improved efficiency, based on clusters with precise structures. Herein, we explore the evolution of the catalytic activity of clusters formed by the structural fusion of icosahedral $\mathrm{Au}_{13}$ units in different modes, namely, $\mathrm{Au}_{25}(\mathrm{SR})_{18}, \mathrm{Au}_{38}(\mathrm{SR})_{24}$, and $\mathrm{Au}_{25}\left(\mathrm{PPh}_{3}\right)_{10}\left(\mathrm{SC}_{2} \mathrm{H}_{4} \mathrm{Ph}\right)_{5} \mathrm{Cl}_{2}$, by evaluating their performance in the oxidation of pyrrolidine to $\gamma$-butyrolactam.

The compositions of the three clusters, as determined by electrospray ionization mass spectrometry (ESI-MS), were $\mathrm{Au}_{25}(\mathrm{SR})_{18}, \mathrm{Au}_{38}(\mathrm{SR})_{24}$, and $\mathrm{Au}_{25}\left(\mathrm{PPh}_{3}\right)_{10}\left(\mathrm{SC}_{2} \mathrm{H}_{4} \mathrm{Ph}\right)_{5} \mathrm{Cl}_{2}$ (Fig. 1(d)-(f)). The frameworks of the three clusters are shown in Figs. $1(\mathrm{a})-(\mathrm{c})$. The $\mathrm{Au}_{25}\left(\mathrm{PPh}_{3}\right)_{10}\left(\mathrm{SC}_{2} \mathrm{H}_{4} \mathrm{Ph}\right)_{5} \mathrm{Cl}_{2}$ cluster exhibits a bi-icosahedral structure obtained by the fusion of two icosahedral $\mathrm{Au}_{13}$ units joined by sharing one vertex gold atom (Fig. 1(a)), denoted as $\mathrm{Au}_{v f}$ (vf: vertex-fused). The $\mathrm{Au}_{38}\left(\mathrm{SC}_{2} \mathrm{H}_{4} \mathrm{Ph}\right)_{24}$ is based on a face-fused (ff) bi-icosahedral $\mathrm{Au}_{23}$ core capped by a second shell comprising the remaining 15 gold atoms. The two icosahedra are fused together by sharing a common $\mathrm{Au}_{3}$ face, yielding the $\mathrm{Au}_{23}$ core (Fig. 1(b)), denoted as $\mathrm{Au}_{\mathrm{ff} .}$ The
$\mathrm{Au}_{25}\left(\mathrm{SC}_{2} \mathrm{H}_{4} \mathrm{Ph}\right)_{18}$ cluster features an icosahedral $\mathrm{Au}_{13}$ core encapsulated by an external gold shell consisting of the remaining 12 gold atoms; in this case, body fusion (bf) results in the formation of an icosahedral $\mathrm{Au}_{13}$ core (Fig. 1(c)), named Aubf. As we can see, the structural fusion of icosahedral $\mathrm{Au}_{13}$ units increases with the growth of the sharing Au atom.

The structural fusion of icosahedral $\mathrm{Au}_{13}$ units in the three clusters results in changes in optical and electronic properties. Fig. S1 shows that the UV-vis optical bands of Aubf are observed at 400, 447, and $683 \mathrm{~nm}$. In the case of Auvf, the UV-vis absorbance peaks appear at 320,416, and $677 \mathrm{~nm}$, whereas the absorbance peaks of Auff are found at 1050, 750, 620, 520, and $490 \mathrm{~nm}$. The UV spectra of the three clusters are in good agreement with previously reported data [19-21]. Differential potential voltammetry curves of the Auvf, Auff, and Aubf clusters at room temperature are shown in Fig. S2. For the Auff clusters, the first oxidation and reduction waves are found at +0.48 and $-0.71 \mathrm{~V}$ (vs. a quasi-reference Ag electrode), respectively. This reveals that the electrochemical energy gap of $\mathrm{Au}_{\mathrm{ff}}$ is $\sim 1.2 \mathrm{eV}$, which is clearly different from that of $\mathrm{Au}_{\mathrm{bf}}(\sim 1.63 \mathrm{eV})$ and $\mathrm{Au}_{\mathrm{vf}}$ $(\sim 1.54 \mathrm{eV})$. After subtracting the charging energy, these values were converted to actual HOMO-LUMO gaps of 1.0, 1.34, and
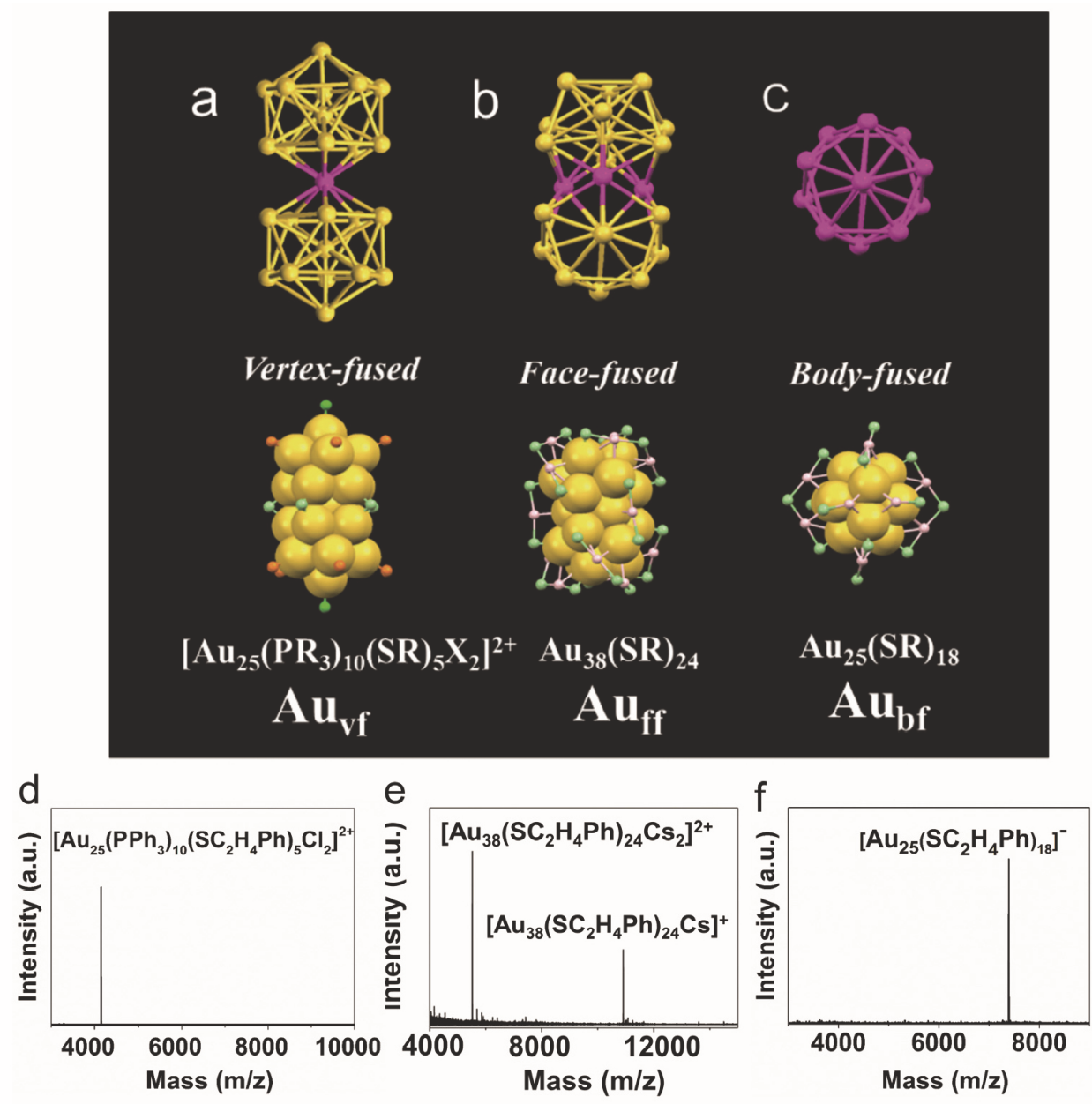

Fig. 1. Structural fusion of icosahedral $A u_{13}$ units: (a) vertex-fused bi-icosahedral $A u_{25}$, (b) face-fused bi-icosahedral Au38, and (c) body-fused icosahedral $\mathrm{Au}_{25} . \mathrm{C}$ and $\mathrm{H}$ atoms are omitted for clarity. Color labels: yellow, pink, and magenta: gold; light green: S; dark green: Cl; orange: P. ESI-MS profiles of (d) $\mathrm{Au}_{\mathrm{vf}}$, (e) $\mathrm{Au}_{\mathrm{ff}}$, and (f) $\mathrm{Au}$ bf. 
$1.21 \mathrm{~V}$ for $\mathrm{Au}_{\mathrm{ff}}, \mathrm{Au}_{\mathrm{bf}}$, and $\mathrm{Au}_{\mathrm{vf}}$, respectively [11,12,2]. These measured gaps are close to the optical energy gaps of $\mathrm{Au}_{\mathrm{ff}}(0.92$ $\mathrm{eV}), \mathrm{Au}_{\mathrm{vf}}(1.31 \mathrm{eV})$, and Aubf $(1.18 \mathrm{eV})$, respectively, obtained from the UV-vis spectra by extrapolation to zero absorbance (Fig. S1). The results show that the three gold clusters exhibit non-metallic behavior.

An important question is whether the structural fusion of icosahedral $\mathrm{Au}_{13}$ units can affect the catalytic activity and, if so, how it can control the catalytic process. In order to address these fundamental questions, the reaction of pyrrolidine with $\mathrm{O}_{2}$ to form $\gamma$-butyrolactam was selected to evaluate the catalytic activity of the Aubf, Auff, and Auvf clusters. First, we examined the catalytic performances of the three clusters loaded on different supports $\left(\mathrm{SiO}_{2}, \mathrm{CeO}_{2}, \mathrm{Al}_{2} \mathrm{O}_{3}\right.$, and $\left.\mathrm{P} 25\right)$ in the pyrrolidine oxidation (Fig. S3). Among the different supports examined, $\mathrm{CeO}_{2}$ was the best choice; in this case, upon the introduction of $\mathrm{O}_{2}$ into the reaction system, the oxygen vacancies of $\mathrm{CeO}_{2}$ can facilitate the oxidation reaction [22]. Note that $\mathrm{CeO}_{2}$ alone had limited activity (Table S1, entry 1), while the pure ligands had no activity (Table S1, entries 3-4). These results indicate that the catalytic performance was mainly determined by the gold sites, rather than the ligands or supports.

Among the three catalysts, $\mathrm{Au}_{\mathrm{bf}} / \mathrm{CeO}_{2}$ exhibited the highest activity ( $\sim 80 \%$ conversion), while $\mathrm{Au}_{\mathrm{vf}} / \mathrm{CeO}_{2}$ gave rise to the lowest activity ( $\sim 40 \%$ conversion). The catalytic activity de- creased in the order $A u_{b f}>A u_{f f}>A u_{v f}$ (Fig. 2(a)). The superior activity of $\mathrm{Au}_{\mathrm{bf}}$ over $\mathrm{Au}_{\mathrm{vf}}$ and $\mathrm{Au}$ uf was also reflected by the reaction rates of pyrrolidine over the three catalysts. The corresponding kinetic profiles for the reaction, shown in Fig. 2(b), not only indicate that the pyrrolidine oxidation was approximately a first-order reaction, but also confirm that the reaction rate constant of pyrrolidine oxidation over Aubf was approximately 1.5-2 times higher than those of the $\mathrm{Au}_{\mathrm{vf}}$ and $\mathrm{Au}_{\mathrm{ff}}$ reaction systems $\left(29.84 \times 10^{-3} \mathrm{~h}^{-1}\right.$ for Aubf, $14.79 \times 10^{-3} \mathrm{~h}^{-1}$ for $\mathrm{Au}_{\mathrm{vf}}$, and $17.21 \times 10^{-3} \mathrm{~h}^{-1}$ for $\mathrm{Au}_{\mathrm{ff}}$ ). The activation energy $\left(E_{\mathrm{a}}\right)$ for $A \mathrm{u}_{\mathrm{bf}}$ was found to be $34.67 \mathrm{~kJ} \cdot \mathrm{mol}^{-1}$, which was lower than those of other two catalysts (Auvf: $66.26 \mathrm{~kJ} \cdot \mathrm{mol}^{-1}$; Auff: $52.71 \mathrm{~kJ} \cdot \mathrm{mol}^{-1}$ ) (Fig. 2(c)). Notably, the influence of the different ligands of Aubf (Fig. S4) on the pyrrolidine conversion, as shown in Fig. 2(d), indicates that the pyrrolidine conversion varied with the chain length of the ligands, with the highest value observed in the case of the Aubf- $n$-butyl mercaptan, followed by Aubf-1-octanethiol and then Aubf-1-dodecanethiol. The conversion was observed to increase with decreasing chain length, which suggests that it is much easier for the pyrrolidine molecules to access the surface gold sites because of the smaller steric hindrance compared to that of long-chain thiolate molecules [23].

Notably, the three catalysts only yielded trace amounts of $\gamma$-butyrolactam in air (0.4 MPa; Table S1, entries 5-7), while an
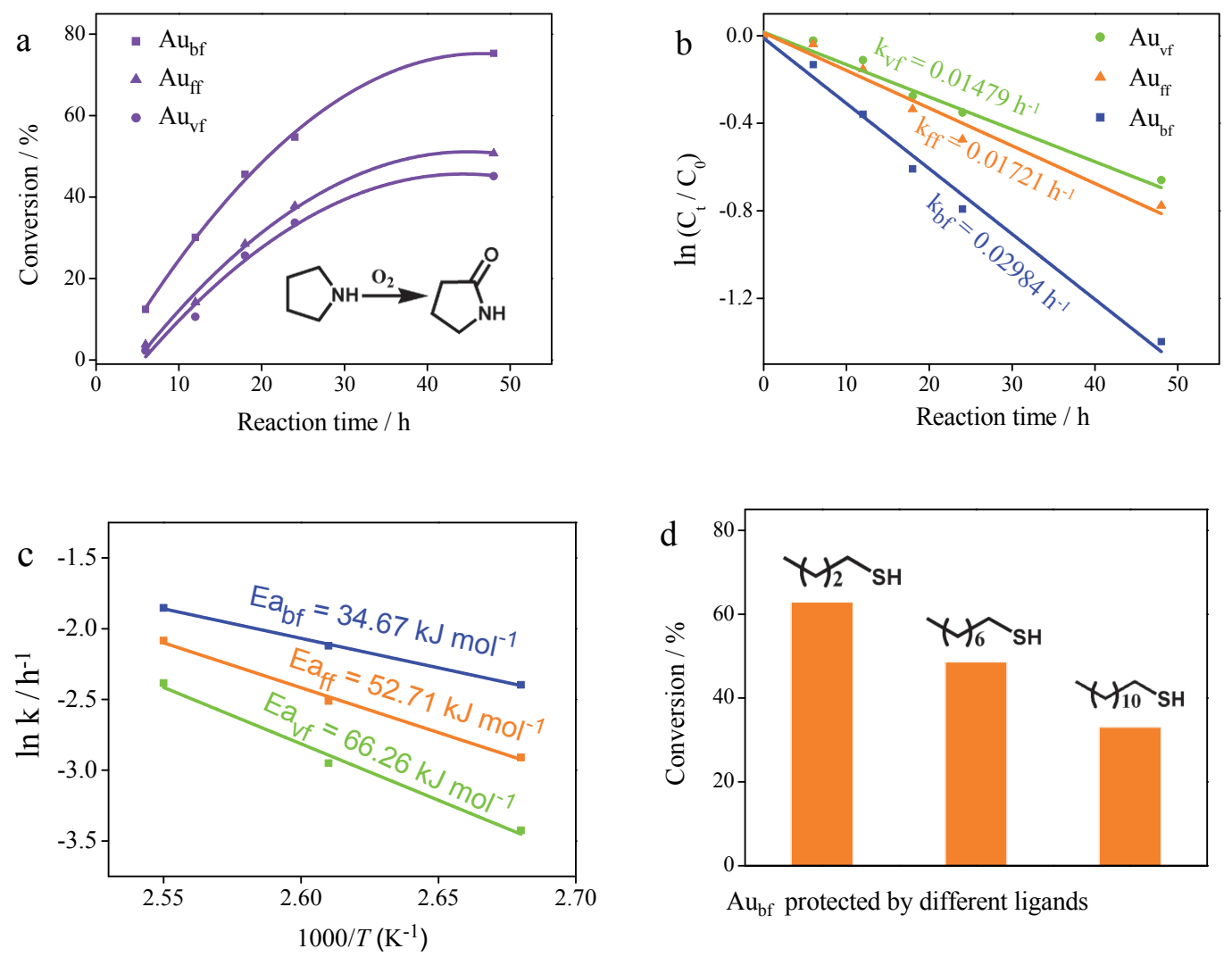

$\mathrm{Au}_{\mathrm{bf}}$ protected by different ligands

Fig. 2. (a) Catalytic oxidation of pyrrolidine over $\mathrm{Au}_{\mathrm{vf}}, \mathrm{Auff}$, and $\mathrm{Aubf}$ catalysts. Reaction conditions: catalyst (100 mg, $\left.2 \mathrm{wt} \% \mathrm{Au}\right)$, pyrrolidine $(0.44$ mmol), $\mathrm{O}_{2}(0.4 \mathrm{MPa}), n$-butanol $/ \mathrm{H}_{2} \mathrm{O}(4.5 \mathrm{~mL} / 0.5 \mathrm{~mL}), 85^{\circ} \mathrm{C}$ for different reaction times. (b) Linear dependence of $\ln \left(C_{\mathrm{t}} / C_{0}\right)$ on reaction time for the oxidation of pyrrolidine over $\mathrm{Au}_{\mathrm{v}}, \mathrm{Au}_{\mathrm{ff}}$, and $\mathrm{Au}_{\mathrm{bf}}$ catalysts. (c) Arrhenius plot for pyrrolidine oxidation. (d) Conversion of pyrrolidine over Aubf catalysts protected by different thiolate groups ( $n$-butyl mercaptan, 1-octanethiol, and 1-dodecanethiol) ( $48 \mathrm{~h})$. 
increasing yield of product was obtained in pressurized air (1 MPa; Table S1, entries 8-10). The reaction did not proceed under $\mathrm{N}_{2}$ atmosphere (1 MPa; Table S1, entries 11-13), indicating that $\mathrm{O}_{2}$ was the oxidant in the reaction. Furthermore, we studied the effect of $\mathrm{H}_{2} \mathrm{O}$ on the catalytic performances. As shown in Fig. S5, the results show that a very low conversion of pyrrolidine $(<10 \%)$ was obtained when $\mathrm{H}_{2} \mathrm{O}$ was absent. An increase in the amount of $\mathrm{H}_{2} \mathrm{O}$ led to an increase in the conversion of pyrrolidine. When the $\mathrm{H}_{2} \mathrm{O}$ amount reached $0.75-1 \mathrm{~mL}$, the conversion decreased, due to ring-opening hydrolysis of $\gamma$-butyrolactam. This suggests that water was necessary for this oxidation reaction.

Under the optimized reaction conditions, we also extended the substrate scope for the reaction. As shown in Table S2, five-, six-, and seven-membered cyclic amines could be oxidized to produce the corresponding amides. In these reactions, Aubf still showed superior activity to $\mathrm{Au}_{\mathrm{vf}}$ and Auff. Furthermore, the clusters exhibited catalytic stability, up to a certain extent (Fig. S6). The UV-vis spectra of the spent clusters dissolved in $\mathrm{CH}_{2} \mathrm{Cl}_{2}$ indicate that the clusters showed no dramatic changes after the catalytic reactions (Fig. S7). The transmission electron microscopy (TEM) images show that the clusters exhibited no obvious aggregation during the reactions (Fig. S8).

Fourier-transform infrared (FT-IR) spectra of CO adsorbed onto the three catalysts were obtained to probe the nature of the available Au sites. As shown in Fig. 3(a), the band at 2168 $\mathrm{cm}^{-1}$ is assigned to gaseous $\mathrm{CO}$ and that at $2117 \mathrm{~cm}^{-1}$ is attributed to $\mathrm{CO}$ molecules adsorbed onto the $\mathrm{Au}^{\delta+}(0<\delta<1)$ sites [24-26]. As we can see, CO was only weakly adsorbed on surface $\mathrm{Au}$ cations, but the relative intensities of $\mathrm{CO}$ adsorbed on the three samples were different, and the chemical adsorption capacity of $\mathrm{CO}$ on $\mathrm{Au}$ sites followed the order $\mathrm{Au}_{\mathrm{bf}}>\mathrm{Au}_{\mathrm{ff}}>$ $A u_{v f}$. It was proposed that the different chemical adsorption capacities of $\mathrm{CO}$ on the clusters might account for the different reactivity of the three catalysts. There were indications of a higher number of catalytic active sites on the Aubf catalyst, followed by $\mathrm{Au}_{\mathrm{ff}}$ and then $\mathrm{Au}_{\mathrm{vf}}$. Fig. 3(b) shows that the peaks at 2158 and $2117 \mathrm{~cm}^{-1}$ decreased in intensity with increasing chain length of the ligands, which reveals that the longer alkyl

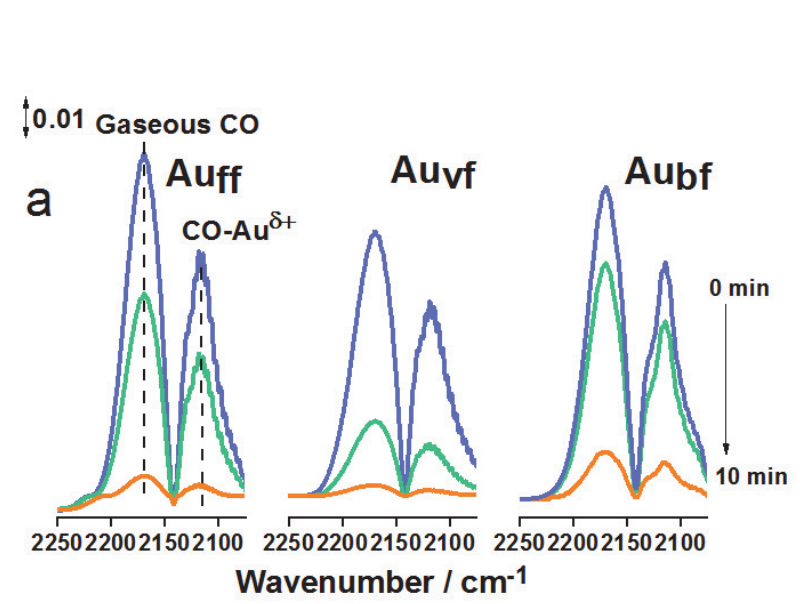

chains led to a higher hindrance, making it more difficult for CO to access the surface Au sites. Therefore, these observations were in line with the consequence of the catalytic activities, supporting the observed evolution of the activity in the pyrrolidine oxidation.

To obtain further insight into the reaction mechanism, the adsorption of pyrrolidine onto the three clusters was investigated via FT-IR spectroscopy. Fig. 4(a) shows that the peaks of the $-\mathrm{NH}$ stretching vibration at $3325 \mathrm{~cm}^{-1}$ of pyrrolidine adsorbed onto the clusters could hardly be seen. The comparison with the IR spectra of pure pyrrolidine and of the three isolated clusters (Fig. S9) reveals that the $-\mathrm{NH}$ group interacted with the clusters, and the $\mathrm{H}$ atom of the $-\mathrm{NH}$ group was mostly removed from the amines and further activated. This indicates that the adsorption of pyrrolidine on the three clusters involved its dehydrogenation process [9]. The X-ray photoelectron spectroscopy (XPS) analysis of the three clusters further highlights the changes in electronic structure upon the structural fusion of $\mathrm{Au}_{13}$ units. As clearly shown in Fig. 4(b) and Table $\mathrm{S} 3$, the shift of the Au $4 f$ binding energies of the Aubf cluster was more positive than those of Auff and Auvf. The XPS data show that the $\mathrm{Au} 4 f$ binding energies of $\mathrm{Au}_{\mathrm{bf}}$ were positively shifted, compared to those of $\mathrm{Au}_{\mathrm{ff}}$ and $\mathrm{Au}_{\mathrm{vf}} \mathrm{Au}^{0}$ and $\mathrm{Au}^{+}$species were detected in the Au $4 f$ spectra of the three nanoclusters. In particular, the $\mathrm{Au}^{+}$species appeared on the surface of nanoclusters, mainly due to the electron donation from the surface $\mathrm{Au}$ atoms to the ligands. The molar ratio of $\mathrm{Au}^{+}$to $\mathrm{Au}^{0}$ was 0.7 for $\mathrm{Au}_{\mathrm{bf}}, 0.63$ for $\mathrm{Au}_{\mathrm{ff}}$, and 0.51 for $\mathrm{Au}_{\mathrm{vf}}$, revealing that Aubf had a more positive charge in comparison with $\mathrm{Au}_{\mathrm{ff}}$ and Auvf. When $\mathrm{O}_{2}$ was used as an oxidant, it could directly attack the $\mathrm{Au}$ atoms to form the $\mathrm{Au}_{\text {cluster }}-\mathrm{O}_{2}(\mathrm{ad})$ species. With respect to the $\mathrm{NH}$ activation of pyrrolidine, the presence of $\mathrm{Au}^{+}$among the surface $\mathrm{Au}$ atoms could substantially activate the nucleophilic -NH group of pyrrolidine, since the surface $\mathrm{Au}^{+}$species are electrophilic [27]. Then, the activated -NH groups reacted with the $\mathrm{O}_{2}(\mathrm{ad})$ species on the surface of the Au clusters. Thus, the more positive charge on the surface Au atoms can lead to a higher catalytic ability to activate the nucleophilic - NH group. On the basis of the XPS data, the activity decreased in the order

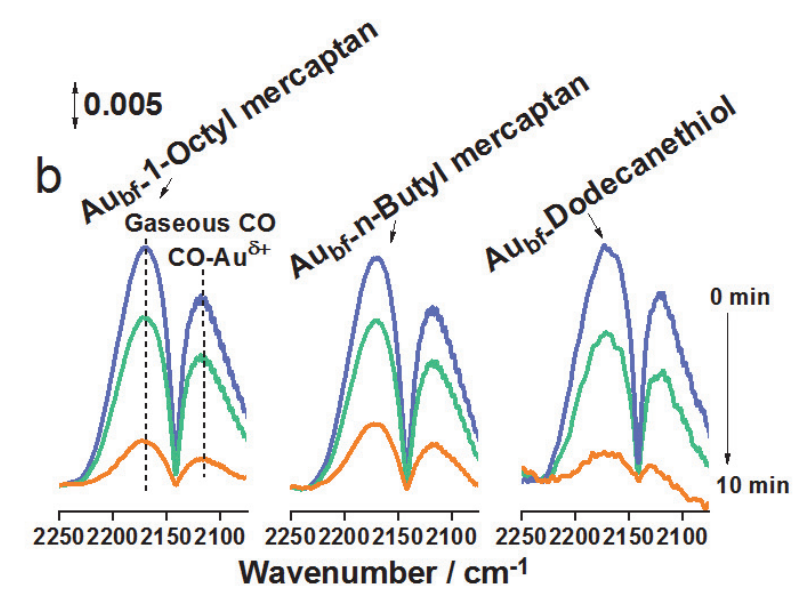

Fig. 3. (a) In situ FT-IR spectra of $\mathrm{CO}$ adsorbed onto the Auvf, Auff, and Aubf clusters; (b) In situ FT-IR spectra of CO adsorbed onto the Aubf clusters capped by different alkanethiol ligands. 

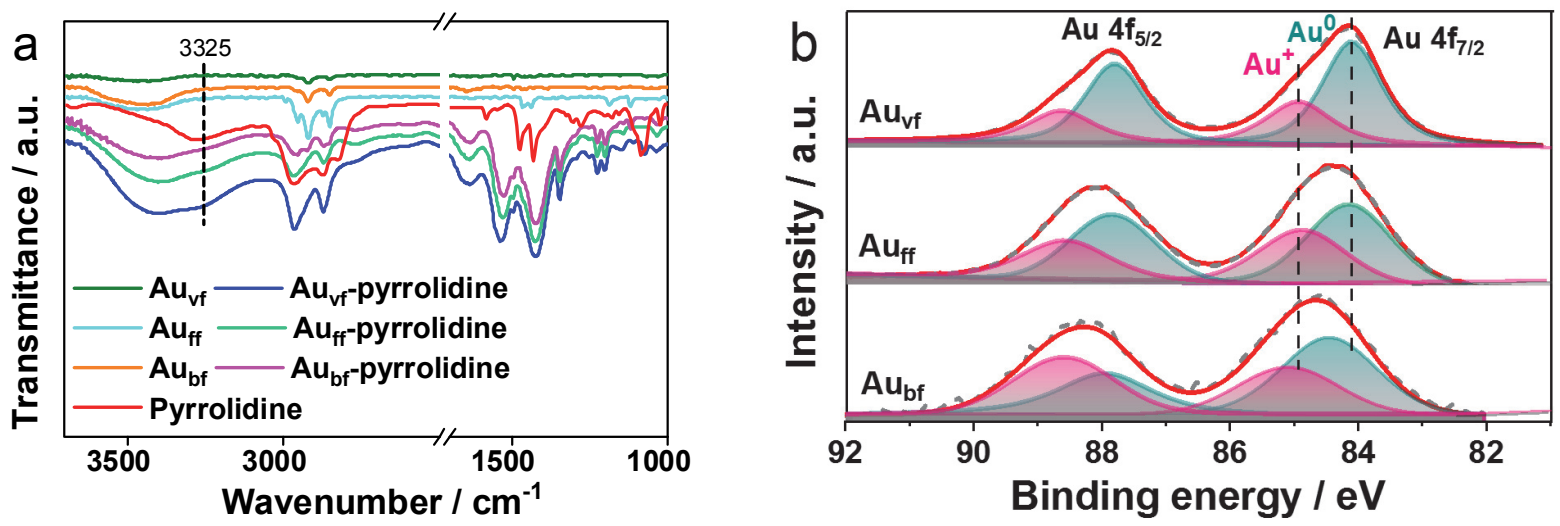

Fig. 4. (a) FT-IR spectra of adsorbed species over the catalysts in the presence of pyrrolidine; (b) XPS profiles of $A u_{v f}, A_{f f}$, and $A u_{b f} c l u s t e r s$.

$A_{\mathrm{bf}}>\mathrm{Au}_{\mathrm{ff}}>\mathrm{Au} \mathrm{u}_{\mathrm{vf}}$, which is essentially in agreement with the experimental results.

Overall, we proposed a possible mechanism for pyrrolidine oxidation on gold clusters, based on the oxidation/hydration/oxidation sequence illustrated in Scheme 1. In the first step, $\mathrm{O}_{2}$ is dissociated into $\mathrm{O}$ atoms on the gold cluster sites and the $\beta$-hydrogen is transferred to the gold sites with release of $\mathrm{H}_{2} \mathrm{O}$, to give the imine product. In the second and third steps, the imine is hydrolyzed and then oxidized to produce $\gamma$-butyrolactam.

In summary, we reported the influence of the structural fusion of icosahedral $\mathrm{Au}_{13}$ units on the catalytic reactivity in the oxidation of pyrrolidine to produce $\gamma$-butyrolactam. The structural fusion of icosahedral $\mathrm{Au}_{13}$ units in the clusters does not distinguish the adsorption modes of pyrrolidine over the three clusters from each other, but modulates the chemical adsorption capacity and electronic properties of the clusters, which is likely to be the reason for the observed changes in catalytic reactivity. This work can be extended to explore the wider catalytic application of non-metallic catalysts with appropriate structural patterns to produce desired products.

\section{References}

[1] T. Higaki, Q. Li, M. Zhou, S. Zhao, Y. W. Li, S. Li, R. C. Jin, Acc. Chem.

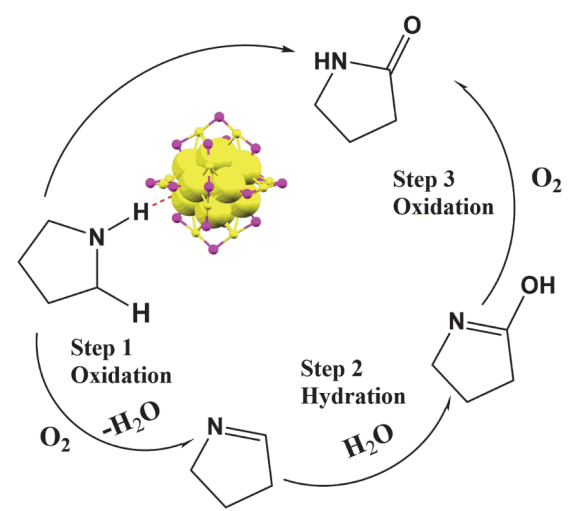

Scheme 1. Proposed mechanism of pyrrolidine oxidation on gold clusters.
Res., 2018, 51, 2764-2773.

[2] B. Nieto-Ortega, T. Bürgi, Acc. Chem. Res., 2018, 51, 2811-2819.

[3] P. X. Liu, R. X. Qin, G. Fu, N. F. Zheng, J. Am. Chem. Soc., 2017, 139, 2122-2131.

[4] I. Chakraborty, T. Pradeep, Chem. Rev., 2017, 117, 8208-8271.

[5] S. B. Tian, L. W. Liao, J. Y. Yuan, C. H. Yao, J. S. Chen, J. L. Yang, Z. K. Wu, Chem. Commun., 2016, 52, 9873-9876.

[6] Z. Lei, Q. M. Wang, Coord. Chem. Rev., 2019, 378, 382-394.

[7] R. Ishida, S. Arii, W. Kurashige, S. Yamazoe, K. Koyasu, Y. Negishi, T. Tsukuda, Chin. J. Catal., 2016, 37, 1656-1661.

[8] H. J. Chen, C. Liu, M. Wang, C. F. Zhang, G. Li, F. Wang, Chin. J. Catal,, 2016, 37, 1787-1793.

[9] Y. Y. Liu, X. Q. Chai, X. Cai, M. Y. Chen, R. C. Jin, W. D. Ding, Y. Zhu, Angew. Chem. Int. Ed., 2018, 57, 9775-9779.

[10] Y. Zhu, H. F. Qian, A. Das, R. C. Jin, Chin. J. Catal., 2011, 32, 1149-1155.

[11] Y. W. Zhang, P. Song, T. Chen, X. D. Liu, T. Chen, Z. M. Wu, Y. Wang, J. P. Xie, W. Lin, Proc. Natl. Acad. Sci. USA, 2018, 115, 10588-10593.

[12] Y. Zhu, H. F. Qian, B. A. Drake, R. C. Jin, Angew. Chem. Int. Ed., 2010, 49, 1295-1301.

[13] Y. Tan, H. Liu, X. Y. Liu, A. Q. Wang, C. J. Liu, T. Zhang, Chin. J. Catal., 2018, 39, 929-936.

[14] J. Xu, M. Chen, Y. Zhu, Chem. Eur. J., 2019, 25, 9185-9190.

[15] S. H. Xie, H. Tsunoyama, W. Kurashige, Y. Negishi, T. Tsukuda, ACS Catal., 2012, 2, 1519-1523.

[16] Z. B. Gan, N. Xia, Z. K. Wu, Acc. Chem. Res., 2018, 51, 2774-2783.

[17] Z. M. Li, X. J. Yang, C. Liu, J. Wang, G. Li, Prog. Nat. Sci., 2016, 26, 477-482.

[18] K. Kwak, Q. Tang, M. Kim, D. E. Jiang, D. Lee, J. Am. Chem. Soc., 2015, 137, 10833-10840.

[19] M. Z. Zhu, E. Lanni, N. Garg, M. E. Bier, R. C. Jin, J. Am. Chem. Soc., 2008, 130, 1138-1139.

[20] H. F. Qian, Y. Zhu, R. C. Jin, ACS Nano., 2009, 3, 3795-3803.

[21] H. F. Qian, M. Z. Zhu, E. Lanni, Y. Zhu, M. E. Bier, R. C. Jin, J. Phys. Chem. C, 2009, 113, 17600-17603.

[22] A. Abad, P. Concepcion, A. Corma, H. García, Angew. Chem. Int. Ed., 2005, 44, 4066-4069.

[23] A. Shivhare, S. J. Ambrose, H. Zhang, R. W. Purves, R. W. J. Scott, Chem. Commun., 2013, 49, 276-278.

[24] Z. Wu, D. E. Jiang, A. K. P. Mann, D. R. Mullins, Z. Qiao, L. F. Allard, C. Zeng, R. Jin, S. H. Overbury, J. Am. Chem. Soc., 2014, 136, 6111-6122. 


\title{
Graphical Abstract
}

Chin. J. Catal., 2021, 42: 245-250 doi: 10.1016/S1872-2067(20)63659-2

\section{Evolution of catalytic activity driven by structural fusion of icosahedral gold cluster cores}

Dan Yang, Yan Zhu *

Nanjing University

Atomically precise gold cluster catalysts have emerged as a new frontier in catalysis science and exhibited unexpected catalytic properties. Here, we demonstrate that the structural fusion of icosahedral $\mathrm{Au}_{13}$ cores to form vertex-fused (vf), face-fused (ff), and body-fused (bf) structures can control the catalytic activity of the clusters.

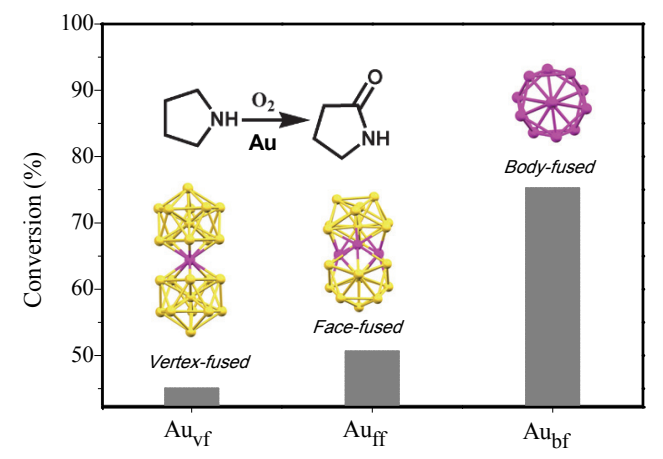

[25] Z. L. Wu, D. E. Jiang, A. K. P. Mann, D. R. Mullins, Z. A. Qiao, L. F. Allard, C. J. Zeng, R. C. Jin, S. H. Overbury, Nano Lett, 2016, 16, 6560-6567.

[26] F. Boccuzzi, A. Chiorino, M. Manzoli, P. Lu, T. Akita, S. Ichikawa, M.
Haruta, J. Catal., 2001, 202, 256-267.

[27] Q. L. Wang, K. Q. Shen, M.Y. Chen, Y. Zhu, Nanoscale, 2019, 11, 13767-13772.

\section{金团簇二十面体结构融合过程中其催化活性的演变}

\author{
杨 丹, 祝 艳* \\ 南京大学化学化工学院, 江苏南京210093
}

摘要: 近年来, 由有机配体保护的原子精确金属团簇在合成方面已取得了重要进展, 其独特的原子结构对一些化学反应产 生独特的催化效果. 原子精确的团簇催化剂明显不同于纳米颗粒催化剂和单原子催化剂, 是一种关联均相和多相的、原子 数目确定、尺寸均一、结构精确的新型催化剂. 从原子尺度上精确构筑团簇催化剂, 探究亚纳米尺度的微观结构对催化性 能的影响, 为常规催化剂所未能解决的关键科学问题提供解决的机会, 为在分子尺度上揭示催化作用机制以及准确关联催 化剂结构与催化性能提供新的研究体系, 具有重要的科学研究意义. 本文设计和使用了三种结构精确的金团簇催化剂, 即 $\mathrm{Au}_{25}\left(\mathrm{PPh}_{3}\right)_{10}\left(\mathrm{SC}_{2} \mathrm{H}_{4} \mathrm{Ph}\right)_{5} \mathrm{Cl}_{2}, \mathrm{Au}_{38}\left(\mathrm{SC}_{2} \mathrm{H}_{4} \mathrm{Ph}\right)_{24}$ 和 $\mathrm{Au}_{25}\left(\mathrm{SC}_{2} \mathrm{H}_{4} \mathrm{Ph}\right)_{18}$, 分别由二十面体结构的 $\mathrm{Au}_{13}$ 单元通过中心顶点融合、面融 合、体相融合形成的(简写为 $\mathrm{Au}_{\mathrm{vf}} 、 \mathrm{Au}_{\mathrm{ff}}$ 和 $A u_{\mathrm{bf}}$ ), 详细研究了这三个金团簇催化剂在二十面体 $\mathrm{Au}_{13}$ 单元的结构融合过程中, 其 催化活性的演变规律. 在催化吡咯烷与 $\mathrm{O}_{2}$ 反应制备 $\gamma$-丁内酰胺反应中, 金团簇催化剂的催化活性顺序为 $\mathrm{Au}_{\mathrm{bff}}>\mathrm{Au}_{\mathrm{ff}}>\mathrm{Au}_{\mathrm{vf}}$, 表明这三个金团簇中 $\mathrm{Au}_{13}$ 单元的结构随着点、面、体的融合, 其催化活性随之增加. 同时研究发现, 对于同一个 $\mathrm{Au}$ 团簇催 化剂, 其表面硫醇配体的烷基链越短, 其催化活性越高, 这主要是由于短链硫醇分子的空间位阻较小, 吡咯烷分子更容易进 入催化剂的金表面, 接触到活性位点, 进行催化反应. 实验表明, 三个团簇金原子均带正电荷, 正价金物种可能是催化吡咯 烷与 $\mathrm{O}_{2}$ 反应的催化活化物种. 研究发现, Aubf 团簇表面的活性位数目高于 $A u_{f f}$ 和 $A u_{v f}$ 团簇的, 因此 $A u_{b f}$ 的催化活性最高; 同 时, 团簇表面配体的烷基链越短, 其表面活性位数目也越多, 这也进一步解释了表面硫醇配体的烷基链越短, 其相应的金团 簇催化剂的催化活性越高的原因. 吡咯烷与 $\mathrm{O}_{2}$ 在金团簇上反应的可能路径为 $\mathrm{O}_{2}$ 在 $\mathrm{Au}$ 活性位上裂解的 $\mathrm{O}$ 原子和吡咯烷 $\beta-\mathrm{H}$ 转移至Au活性位的 $\beta$-H反应脱水后形成亚胺, 亚胺经过水解进一步氧化得到产物. 这项研究将为在原子层次上调变金属团 簇催化剂的结构进而改变其催化性能提供新的思路, 对精准设计和构筑高效催化剂具有一定的科学指导意义.

关键词: 金团簇; 结构融合; 二十面体结构; 吡咯烷氧化; 活性位点; 催化活性

收稿日期: 2020-04-18. 接受日期: 2020-05-21. 出版日期: 2021-02-05.

*通讯联系人.电话: (025)89681696; 电子信箱: zhuyan@nju.edu.cn

基金来源：国家自然科学基金(21773109, 91845104).

本文的电子版全文由Elsevier出版社在ScienceDirect上出版(http://www.sciencedirect.com/science/journal/18722067). 